\title{
Maurice Bellet, Mystic of the Human
}

\author{
Mihai-IUlian DANCĂ $\breve{A}^{*}$
}

This study focuses on one outstanding theologian from the Church in France; his writings have influenced a whole generation of priests and laity seeking a Christianity that they were on the point of abandoning. In his search for the origins of this disenchantment, Maurice Bellet takes a fresh and unexpected look at the Christian faith, the Church and the society of his time.

Keywords: French Church, post Vatican II, hope, human, abyss, light

Maurice Bellet would have been more surprised than anyone else to be known in this way. Better known as a theologian, a philosopher and an atypical psychoanalyst, only rarely is he considered a mystic. And yet, the name of Maurice Bellet (1923-2018) cannot be separated from the post Vatican II renewal and from the spirituality that marked the French Church in the second half of the $20^{\text {th }}$ century.

That period was in his own words "the time of hopes"1 when, in the wake of so many others, he believed that the Council was going to change everything. What was in question, no more and no less, was starting Christianity again, as had been done by the monks in the past: "In the IVth century the deserts were filled with monks" ${ }^{2}$ said a famous Romanian monk. It has to be said that Christianity, at heart, never stops being re-born: as in the time of Francis of Assisi, of Ignatius of Loyola, of Martin Luther and closer to our own time, of Blessed Charles de Foucauld, the Second Vatican Council. The Church is, more than anything, a process, a dynamic of the Spirit, a Word of Life.

The work of Maurice Bellet bears the hallmark of this hope of the renewal which the Council had enkindled. For him, we were participating in the beginning of a new Church, which would be less institutional and western, closer to the people, and more concerned about its existence. Let us really pay attention to that vocabulary: beginning, newness, change, birth. One would do well to see it as a krisis, as the word is used by Heidegger to distinguish between the first beginning and any other begin-

\footnotetext{
*Mihai-Iulian Dancă, Assumptionist Father, director of the St Peter and Andrew Center of Bucharest, General Christian Tell, 18B, 010386, Bucharest, dancaiulian@yahoo.it.

${ }^{1}$ Maurice Bellet, La longue veille: 1934-2002 (Paris: Desclée de Brouwer, 2002), 121.

${ }^{2}$ André Scrima, Despre isihasm (București: Humanitas, 2003), 27.
} 
ning $^{3}$. At the confluence of two worlds, therefore, we find the Council as krisis: "not an end but a beginning, not a balance sheet but a clean slate." That will help us to enter more fully into the writing of Maurice Bellet, which will be poorly understood if one only sees in it the act of a rebel. It is much more about someone writing with the awareness that in the Church "everything was going to change." In an article written in 1965, "Dangers of enthusiasm," he moves away from polarized positions (e.g., progressives versus traditionalists) in order to stress what he considered to be the urgent task of the Church with regard to that particular Council: to work for the "real human person," "to open oneself to the world," to bring to birth "a new kind of Christian." 7 These are expressions which at first sight seem banal, familiar and conventional, but which, on reflection, signal a huge undertaking, for it is a question of reconstructing the "new" human person, who is none other than the "new" Jesus Christ, the real presence of God in humanity, and men and women are seen as "the image of God" (imago Dei).

This topic stayed with him until practically the end of his life, for he saw in it the source of all contemporary crises. This is behind the collapse of ideologies, the illusion of technological progress, economic crises, philosophical sterility, in short "the usury of the world," ${ }^{8}$ of a certain kind of world. Later we will see that the leitmotif of Maurice Bellet's work is in fact quite simple but, by that token, all the more true: how can the Church take on human existence?

We must understand this last expression in the wider sense, not ontologically, but in a phenomenological sense, as seen for example in the work of Michel Henry, who sees existence as a mysterious manifestation of the Life which comes from God: "Wherever there is Life, this self-revelation [of God] is produced." Wherever men and women live by the Gospel, God is present. For Maurice Bellet, that goes beyond institutions, denominational criteria, and proselytisms which are suspect. It is a question of putting into action the message of Christ in a way which is both real and effective.

\footnotetext{
${ }^{3}$ Martin Heidegger, Beiträge zur Philosophie (Vom Ereignis) (Frankfurt am Main: Vittorio Klostermann, 2003), 295.

${ }^{4}$ Bellet, "Périls de l'enthousiasme," in Passer par le feu. Les années Christus (1965-1985)

(Paris: Bayard, 2003), 44.

${ }^{5}$ Idem, La longue veille, 121.

${ }^{6}$ Idem, "Périls de l'enthousiasme," 38-42.

7 Ibidem, 45.

${ }^{8}$ Idem, "Passer par le feu," in Passer par le feu, 276.

${ }^{9}$ Michel Henry, C'est moi la vérité. Pour une philosophie du christianisme (Paris: Editions du Seuil, 1996), 40: "Partout où il y a Vie, cette auto-révélation [de Dieu] se produit".
} 
Therefore, it is to accomplish the most difficult task of being where one is constantly fighting against "the violence and blindness of people" 10 . It is to take up a position where one is in opposition to the established order.

\section{Who was Maurice Bellet?}

A prolific author (sixty books and countless articles of his were published), Maurice Bellet has remained nevertheless on the periphery of the Church; yet, despite his iconoclastic thinking, he was never condemned by the Hierarchy. His closest collaborator, Myriam Tonus, author of the only book introducing us to Maurice Bellet's work, echoes the same astonishment, both on behalf of the readers and of Maurice Bellet himself: "I have no explanation, he replied. What I write is perfectly orthodox as far as the great Tradition is concerned. Or maybe those in the upper echelons of the Church don't read me. Or maybe they don't understand..."11

It must also be said that he is not so much concerned with critiquing doctrine per se as with the witness that the Church gives and its fidelity to Christ's message. Moreover, he wrote an article on this subject in which he shows his opposition to what he calls "the two Christianities": the first, roughly speaking, is the Christianity of the catechism, the second, the Christianity of agapêt $\hat{e}^{12}$.

Indeed, as we continue to read, we discover that Maurice Bellet is a man who is deeply attached to his Christian faith, but that his attachment is expressed by his very personal approach to living and understanding it. This leads to a written work which is unique in the theological landscape, closer to poetry than to scholarly rigour. Those who read him for the first time may be delighted by his writings, or they may be completely put off. Therefore, to those who complain about the difficulty of his writing, Myriam Tonus advises reading his texts aloud:

I conducted an experiment during the introductory sessions on his work. I would first read a page from L'Extase de la vie ("Life's Ecstasy"), in a recto tono mode, without the slightest modulation, in a perfectly neutral voice. At the end of my reading, I would ask the participants what they thought of it, and the conclusion would

\footnotetext{
${ }^{10}$ Bellet, "Les deux christianismes," in Passer par le feu, 239.

${ }^{11}$ Myriam Tonus, Ouvrir l'espace du christianisme (Paris: Albin Michel, 2019), ePub edition, chap. 3, sub-chap. "L'advenue d'une Parole".

${ }^{12}$ See: Bellet, "Les deux christianismes," 238. Maurice Bellet, in this sense, is not another Hans Küng, more inclined to critique the truths of faith than the way they are lived. What they have in common, however, is a desire to go back to the origins, to return to a more authentic Word.
} 
be, "Obviously, it's complicated!" Then I would re-read the same page, but this time speaking it, interpreting it, as if it were a story, or a poem, or just a conversation. And then, a great surprise: "It works!" some would say; "I don't understand everything, but I find it beautiful", others would observe. ${ }^{13}$

We do not have many sources from which to sketch Maurice Bellet's portrait, apart from the only autobiographical book he bequeathed to us, $\mathrm{La}$ longue veille: 1932-2002 (“The Long Watch: 1932-2002”). And, of course, there is Myriam Tonus' book, which also gives us a beautiful portrait of Maurice Bellet through some of her personal memories. La longue veille, which will be the main focus of this article, consists of four meditations of unequal length, corresponding to four periods of Maurice Bellet's life, marked by the years 1934, 1979, 1995 and 2002. Covering a span of almost seventy years, this so-called autobiography was not written all at once, but it consists of a collection of manuscripts bound in a single book. It cannot be said that the book follows a linear course; rather, it is a re-reading conducted in the light of his faith. The chronology is that of affective memory, which is why it is sometimes difficult to assess the accuracy of each biographical element. Nor was this the intention of Maurice Bellet, who cared little for such rigour: "I am confused about the dates. What year? 1962, perhaps. It was during the Council." ${ }^{14}$ One thing that strikes us is the almost unchanged style of his writing, as shown in these three lines dating back to 1934 . The incredible maturity they display makes it hard to believe they were written by an eleven-year-old child: "Transforming violence into force, / Chimerical thoughts: very dangerous, transforming them. / Overcome violence by joyfulness." ${ }^{5}$ Therefore, this book should not be considered a biography in the classic sense of the term, but rather a kind of modern Confessions, the book of a mystic who, while recounting his life, never stops questioning his disenchanted, technical and de-Christianized age.

The few biographical elements that we can extract from his book tell us that he was born on December 19, 1923, in Bois-Colombes, a small town located in the north-west part of the Parisian suburbs. He spent his childhood in the nearby town of Bécon-les-Bruyères, where the Bellet family lived in an apartment for fifteen years, before the Second World War broke out. Having expressed a desire for the priesthood, he entered the Minor Seminary of Conflans and then the Major Seminary of Issy-les-Moulineaux

\footnotetext{
${ }_{13}$ Tonus, Ouvrir l'espace du christianisme, chap. 1, sub-chap. "Une écriture qui chante".

${ }^{14}$ Bellet, La longue veille, 105.

15 Ibidem, 9: "Transformer la violence en force, / Pensées chimériques : très dangereux, les transformer. / Triompher de la violence par la gaité”.
} 
for theological studies, and the Carmelite Seminary for philosophical studies. Between 1943 and 1944, he graduated in philosophy from the Sorbonne. The war mobilized him for a short period in Melun at the end of 1944 . Because of his frail health, he was hospitalized after one month, and then assigned to the service of the gunsmiths, i.e., those who guarded the weapons depot. He was ordained a priest in Bourges in 1949, and was immediately appointed professor of philosophy at the Petit Séminaire de Saint-Louis near Bourges, where he taught for fifteen years. At the Major Seminary of Bourges, he became friends with Jean Trouillard, a Sulpician priest and a Plotinian philosopher, the Rector of the Seminary, who practically educated him in philosophy.

Author of three doctoral theses in Philosophy, he wrote them, in his own words, "without a single note, without a single reference, without a bibliography! The height of arrogance!" 16 The first thesis, written when he was studying for a university doctorate in Philosophy under the supervision of Jean Guitton, is called: Vocation et Liberté (Vocation and Freedom) ${ }^{17}$. The writing method was original to say the least: "I remember writing the text, and then adding the notes for the sake of academic decency." 18 In June 1968, he simultaneously defended two other State doctoral theses, before an impressive jury: Paul Ricœur, Emmanuel Levinas, Clémence Rammoux, Olivier Lacombe and Henry Duméry. The first thesis is called La Fonction critique dans la certitude religieuse ${ }^{19}$ (The Critical Function in Religious Certainty), and the second, now lost and without any indication of a title, was "on the difficulty of the word of meaning." ${ }^{20}$ In the period when he was defending his doctoral dissertations, the atmosphere was still heavy with the May ' 68 protests, and Maurice Bellet remembers this surreal scene when, during the defence session, "through the window behind the jury, I could see falling like snow scraps of paper from texts and documents that the student protesters were tearing up on the floor above." ${ }^{21}$ Finally, a fourth thesis, this time in Theology, and written under the direction of Claude Geffré, would be published under the title Le Déplacement de la religion ${ }^{22}$.

\footnotetext{
${ }^{16}$ Ibidem, 177.

${ }^{17}$ Published by Desclée de Brouwer, 1963.

${ }^{18}$ Bellet, La longue veille, 199.

${ }^{19}$ Later published by Desclée de Brouwer as Essai d'une critique de la foi, 1968.

${ }^{20}$ Bellet, La longue veille, 200-201.

${ }^{21}$ Ibidem, 199.

${ }^{22}$ Published by Desclée de Brouwer, 1972.
} 


\section{An unclassifiable work}

Maurice Bellet is an author who immediately stands out for his distinctive personal style. The critics call him an "unclassifiable" writer, a designation he takes as a "compliment" ${ }^{23}$, but which was also to give him trouble: "It gave me some problems, starting with the impossibility of making myself understood" 24; "I'm not in my place. Have we ever been?" 25 , he would wonder. Nevertheless, at the time of putting together his autobiographical book in 2002, he was already the prolific author of sixty books, a good hundred articles for the review Christus ${ }^{26}$ (of which he was a faithful collaborator from 1965 to 1985 and where he befriended Michel de Certeau), and scores of other articles in numerous journals.

Maurice Bellet's books will never leave you indifferent. One reader compares one of his books to a "silent companion" 27 , another thanks him for having echoed her own torments: "Thank you for listening to me..." ${ }^{28}$; finally, another reader talks about his books as something that helped him to "avoid psychiatry," ${ }^{29}$ etc. Even more astonishing is this memory of Myriam Tonus:

At the end of his life, he learned that one of his books lay permanently on a bishop's bedside table, and that another had apparently responded to one of his colleagues who was disturbed by the audacity of Bellet's thought: "Maybe. But he helps so many people!"30

His books, however, in no way resemble therapeutic prescriptions. Is it perhaps the style of writing, or the disarming sincerity of the author that touches the readers? His first book, La Force de vivre, begins with these words: "We sometimes lose the taste for living." ${ }^{1}$ This is far from being highly motivating reading! Or this other sentence from his father, which devastated him: "The Church has over-stuffed our heads." 32 In the 1979 manuscript, he states that he had come to know only two religions during his life: the

\footnotetext{
${ }^{23}$ Bellet, La longue veille, 204.

${ }^{24}$ Ibidem, 205.

${ }^{25}$ Ibidem, 206.

26 The review Christus paid him tribute in the special issue no. 262 of May 2019: Maurice Bellet. Suivre le Christ aujourd'hui ("Maurice Bellet. Following Christ today").

${ }^{27}$ Bellet, La longue veille, 190.

${ }^{28}$ Tonus, Ouvrir l'espace du christianisme, chap. 1, sub-chap. "Une écriture qui chante”. A reaction from a reader after having read La Traversée de l'en-bas.

${ }^{29}$ Bellet, La longue veille, 190.

30 Tonus, Ouvrir l'espace du christianisme, chap. 3, sub-chap. "L'advenue d'une Parole".

${ }^{31}$ Bellet, La longue veille, 107.

${ }^{32}$ Ibidem, 13.
} 
first, the religion of love; the second, the religion of sadness. ${ }^{33} \mathrm{We}$ of course recognize them as two facets of the same Christianity, the sublime and the abhorrent. What is really at stake in Maurice Bellet's writing is our ability to rediscover the essential flavour of the Gospel, its radical demand, and its omnipotence through and within our humanity. This is why La longue veille is a first-hand source for getting to know what lies behind this prolific writer, for helping us to recognise the stature of a great mystic.

\section{Hope as faith in man}

If there is one major trait that could characterize the work of Maurice Bellet, it would be the word hope; when written by him this word indicates "that which does not yet exist." 34 Hope is one of the reasons that prompted him to write La longue veille, "to regain momentum - says he -, to set off again at a brisk, and sometimes furious pace, across all that landscape of disappointments and rubble, in order to go further." ${ }^{35}$ This rage is also what lies behind the fiery language and expressions which come like bolts of lightning. But more deeply still, he writes in order to engage in "the only fight that counts: the fight against death." ${ }^{36}$ For Maurice Bellet, there is always a "beyond death" that begins each time with human attitudes such as "the loving voice, the benevolent gaze, the non-judgmental listening, the shared food, the gift without any hidden thought or motive," ${ }^{37}$ etc. Christianity is for him that path of humanity that the Church urgently needs to rediscover. This was, among other things, one of the preoccupations of Gaudium et Spes:

he joys and the hopes, the griefs and the anxieties of the men of this age, especially those who are poor or in any way afflicted, these are the joys and hopes, the griefs and anxieties of the followers of Christ. Indeed, nothing genuinely human fails to raise an echo in their hearts (GS 1).

There we see an intuition which Maurice Bellet develops to the full: anything truly human can be no stranger to Christ and that includes the Church itself. If the Church is fraternal (agapê), then there is no longer any barrier between it and the rest of humanity. One asks oneself, of course, what the essence of that Church is. Its doctrines? Its institutions? Or that which is at play in what is beautiful and true in all human relationality? For Maurice Bellet the first characteristic of the human reality is that it is "completely

\footnotetext{
${ }^{33}$ Ibidem, 13-14.

${ }^{34}$ Ibidem, 15.

${ }^{35}$ Ibidem, 20.

${ }^{36}$ Ibidem, 21.

${ }^{37}$ Ibidem, 30.
} 
penetrated by the totality of Christ." 38 Therefore, this association between the Church and humanity entails for the former a certain number of hurdles to be overcome. There are four of them:

- Overcoming the opposition between the Church defining itself by explicit reference to Christ (in an "exclusive" way) and the rest of humanity.

- Overcoming the opposition between the salvation of Christ and the salvation of Man in his present condition.

- Overcoming the opposition between the witness of Christ solely in the Christian tradition and "his" presence in the rest of humanity.

- Overcoming the opposition between the language used by Christians and the language used by other cultures to speak of Christ. ${ }^{39}$

These are the reasons why one can say that what happened at the Council was in this respect foundational. Not so much in its historic materiality but in what it inaugurated for the whole Church, in its openness to the world of today, in its awareness of humanity as the primary focus of the Gospel. Maurice Bellet merely took up again the seeds of thought planted during the Council.

But, here, the problem is that "as soon as it starts to burn too much, the tremendous glaciation of speech begins," ${ }^{40}$ that is to say those hollow statements, those soul-less letters, those lukewarm speeches. This can only anger Maurice Bellet who will say in one of his harshest sentences: "How I hate this world, its sufficiency, its pompousness, its false work, its foolish fashions." ${ }^{41}$ Maurice Bellet's language contains a certain violence, the meaning of which needs to be well understood. As Myriam Tonus specifies:

the word violence is ambiguous, according to Maurice Bellet. It can designate primordial violence: that powerful force which "is born, grows, repels and defeats that which gets in its way" ${ }^{42}[\ldots]$ But there is also, of course, that violence which is «rage to destroy, excess and deviance». ${ }^{43}$

From that point on, is there not something in this indignation of Maurice Bellet, a sort of prophetic verve, which constantly calls for faith, especially when faith seems to lie dormant? We will find this even in the writing of a

\footnotetext{
${ }^{38}$ Bellet, La peur ou la foi. Une analyse du prêtre (Paris: Desclée de Brouwer, 1968), 325.

${ }^{39}$ Ibidem, 326.

${ }^{40}$ Idem, La longue veille, 32.

${ }^{41}$ Ibidem.

${ }^{42}$ Idem, "Je ne suis pas venu apporter la paix...": Essai sur la violence absolue (Paris: Albin Michel, 2009), 23-32, apud Tonus, Ouvrir l'espace du christianisme, chap. 2, sub-chap. "Ce qui est nécessaire à l'humain".

${ }^{43}$ Ibidem.
} 
Paul Evdokimov, whose words for denouncing the tepidity of Christian faith might seem to vie with those of Maurice Bellet:

Everything is so well contained in symbols, signs or words, that any desire to pass to the signified and symbolized realities causes astonishment and anxiety... Everything is average and gray, like in all righteous environments: average gifts, moderate meetings, catechism without flame, boredom... ${ }^{44}$

The ambiguity of the language thus masks a violence which comes from further away, from the depths of what Bellet calls "crucified memory" (mémoire (rucifiée) $)^{45}$, an expression which designates the suffering born from the inability to unify the expectations of the world with those of the Gospel. "Carrying that cross" 46 is the challenge for every human being. However, we know that the non-choice of the Cross, which does not condemn anything and which assumes everything, is a source of great suffering and discomfort. It means there is a "great gap" between what we accept and what we condemn, between what we choose and what we reject, and between what is allowed and what is forbidden. Do we not recognize here a certain Church discourse, "the City of God" against "the city of humankind"? Such is the suffering of the Cross: to die to the impulse to choose and exclude. Now, the God who is born through the Cross, is always greater, "constantly greater" 47 than all we know of and about Him.

\section{Seeking God and finding man}

We are reminded of the Eckartian "opportet transire": concerning God, one must never stop moving on, never stop going further. This is the strength of the Cross that generates a new world and a new humanity. The expression Maurice Bellet uses to describe this world is "even though..." (même si) an expression that we find throughout the entire Bible: "Even though the people have forgotten Yahweh and they dance around the golden calf... Even though we have crucified the Lord..." 48 . The Christian faith is the faith-hope of this "even though..." that is of the new world born out of our ruins. It is the belonging to this world that drives Maurice Bellet to say: "I am from another world" ${ }^{49}$; it is the world of love opposed to the world of

\footnotetext{
${ }^{44}$ Paul Evdokimov, La femme et le salut du monde (Paris: Desclée de Brouwer, 2009), 251-52.

${ }^{45}$ Bellet, La longue veille, 33.

${ }^{46}$ Ibidem, 34.

${ }^{47}$ Ibidem, 37.

${ }^{48}$ Ibidem, 39-40.

${ }^{4} 9$ Ibidem, 44.
} 
horror (which Maurice Bellet brings to mind by pointing to the existence of wars, genocides, the Third Reich, Communism). Every time men and women relinquish their darkness, and resist the temptation of evil, a new world appears on the horizon. This new world consists, for example, in the sublime words of his father when he speaks of his wife, and therefore, of his mother: "and then, what can you say, she is joyful." ${ }^{0}$ In these words, we see the same "even if..." at work, we see hope triumphant over the failures of human beings. For Maurice Bellet, his father's words are proof that "the depths of man are, in spite of everything [...], just light.." It's the light of Easter, once death is over. It is the beyond-death, the "beginning" of the new world.

The horizon of the conjunctive phrase "even if ..." is from then on eschatalogical. It alone allows us to see in the precarious nature of our world, the seeds of the kingdom. Rainer Maria Rilke had a marvellous expression to translate that hope: "God is ripening" (Dieu mûrit) $)^{52}$. It is the seed of life and of humanity which is growing in the world: "while he [the farmer] sleeps or when he is awake, the seed is sprouting and growing; how, he does not know" (Mk. 4:27).

Maurice Bellet has sometimes been compared to a Christian Nietzsche ${ }^{53}$. In a description of the Christian religion, which is reminiscent of that of the German philosopher, he speaks of "that backward path" 54 which Christ established in the world; this path is a:

je-ne-sais-quoi which has no name in our language and which eradicates, clears away, removes all the metamorphoses that hide and cover the great Abyss; which removes the huge reassuring stone from the Mausoleum, where we worship the Great Corpse. The stone is rolled away: the tomb is empty. No longer does there exist a holy place! There is no longer any protection against fire falling on the earth. ${ }^{55}$

There is, obviously, in Maurice Bellet, a radical apophatism which can be explained by Neo-Platonic philosophical training and by his reading of cer-

\footnotetext{
${ }^{50}$ Ibidem, 64.

${ }^{51}$ Idem, Dieu personne ne l'a jamais vu (Paris: Albin Michel, 2008), 95: "Perhaps, then, believing in God consists of this: to believe that in every human being there is this point of light."

${ }^{52}$ Rainer Maria Rilke, Le livre de la vie monastique, in CEures poétiques et théâtrales (Paris: Gallimard, 1997), 279.

53 https://www.la-croix.com/Culture/Livres-et-idees/Le-Dieu-pervers-Maurice-Bellet2018-07-12-1200954543, accessed March 25, 2020.

${ }^{54}$ Bellet, La longue veille, 73.

${ }^{55}$ Ibidem.
} 
tain mystics like Dionysius the Areopagite or Master Eckhart. He has great admiration for Jean Trouillard, the philosopher he would visit regularly in Bourges and of whom he said he was one of the few men who dared to "think": "Jean Trouillard thought. And he would disprove, with his peaceful and benevolent criticism, what I desperately constructed to oppose his implacable idealism." ${ }^{56}$ In his interaction with the man, "frightened" by the loss of his bearings, Maurice Bellet gets caught up in the game, and from their exchanges one day he will be inspired to pronounce this admirable sentence: " "About the absolute we can say nothing, not even nothing.» He liked it; I was flattered." ${ }^{57}$ Or this other sentence worthy of the greatest mystics: "The void, the void, and the void of the void." 58 This is the price for getting close to God, to be completely stripped. But then, what is left of this radicalism that Maurice Bellet claims at all times?

What do we have left? What is left when nothing is left? This: that we be human towards humans, that among us there remains that "among-us" (qu'entre nous demeure l'entre nous) that makes us human. Because if that were to fail, we would fall into the abyss, not of the bestial, but of the inhuman or the dehuman (linhumain ou $d u$ déshumain), the monstrous chaos of terror and violence and of a violence in which everything is torn apart. ${ }^{59}$

The mysticism of Maurice Bellet provides neither ecstasy, nor a beatific experience, nor rapture of the soul. It is rather the confrontation with man's "fallen nature", and for this reason, far from being overflowing joy, it is "sadness":

this sadness of darkness, this bitterness that hates birth and life; for it is from this abyss that cruelties, abandonments, withdrawals, anxieties arise. This is where the extreme comes from, the inhuman - the unimaginable coldness of those who organize massacres. And where does this sadness come from? It comes from the fact that a word has not been said. Or that it has been killed. This word [...] is just the presence of 'human tenderness', it is the warmth of the loving body which becomes poetry and thought, transfiguration of the body, liberation from judgment, a presence which releases from hell. ${ }^{60}$

${ }^{56}$ Ibidem, 89.

${ }^{57}$ Ibidem.

${ }^{58}$ Ibidem, 90.

${ }^{59}$ Idem, Incipit ou le commencement (Paris: Desclée de Brouwer, 1994), 8, apud Tonus, Ouvrir l'espace du christianisme, chap. 1, sub-chap. "Une écriture qui chante".

${ }^{60}$ Idem, L'Amour déchiré (Paris: Desclée de Brouwer, 2000), 158-59, apud Tonus, Ouvrir l'espace du christianisme, chap. 2, sub-chap. "Ce qui est nécessaire à l'humain”. 
Sadness is therefore "this pain of not being able to be born..." ${ }^{61}$ to "human tenderness". All things considered, it is not very different from the compunction experienced by the Hesychast monk. If "ecstasy" is to exist at all, it will have to go through:

the exaltation of discovering, of being invaded by the new, of sensing that what is being proclaimed, (through the words that seek each other), is the word, The Word which opens us out to the great Possible, which draws humans out from their deadening sleep. It happened to me. ${ }^{62}$

What exactly? Probably being born, by the grace of a life-giving word. This word, for example, can be in the words of Christ whenever He forgives, consoles, comforts and heals us humans.

\section{The victorious laugh}

But apparently, tasting these words is dangerous for Order which fears their power, and that is why it seeks to "codify them, subdue them, mummify them," ${ }^{3}$ in short, to kill them. Order is of course a specific world outlook, with its safety measures gone mad, its dictatorships, and all the systems which prevent man from being reborn to a new life. Even more serious, Order can also become a certain image of God, which Maurice Bellet calls the "perverse God" (Dieu pervers) ${ }^{64}$.

The iconoclasm of Maurice Bellet is not a fight against faith or against the Church in the name of some progressive, humanist ideology. On the other hand, there is indeed in him a fight to "destroy religion" 65 each time that religion identifies with Order, and with everything that characterizes it: pompousness, banality and mediocrity. Although the expression may be shocking, we must grasp the radicality of what is sought: to understand "destruction" in the sense of a purification, a freedom, a nomadism. Consequently, this destruction is salutary because it makes it possible to release "what it holds in it [...], something of an unimaginable violence, a violence converted into Way,

${ }^{61}$ Idem, La longue veille, 105.

${ }^{62}$ Ibidem, 111.

${ }^{63}$ Ibidem.

${ }^{64}$ Ibidem, 134 : "The perverse God is the terrifying, monstrous figure that appears when the falsely sweet figure of the loving God is torn apart; but the process of major perversion is found everywhere: when the best is home of the worst, when the truth is the instrument of lies, the exaltation of life is the triumph of murder". This expression became the title of one of Maurice Bellet's best known books, Le Dieu pervers (Paris: Desclée de Brouwer, 1979).

${ }^{65}$ Ibidem, 113. 
Truth, Life." ${ }^{66}$ This incredible thing is never sure of its success. What, after all, is the Cross, if not this sign of the death of God, and on Christ's face, of the death of "God with a human face" 67 ? This is proof that the transition to life can only be made at the cost of this vertiginous descent "into the abyss of the abyss itself." ${ }^{68}$ And, at the bottom of this abyss, there is the light of "even though..." a light that Maurice Bellet compares to "a song sung with closed lips by the sea." ${ }^{69}$ The new humanity thus begins in the figure of the Child Jesus. An amazing path that leads from the Cross to childbirth. But this is what it is all about: this new reality "which laughs up one's sleeve at the pretence of the wise and the learned." ${ }^{70}$

For Maurice Bellet, the true force of the Gospel is the capacity "to love our brothers, to love them thoroughly, in truth, for themselves, without ulterior motives, freely." ${ }^{\prime 1}$ On this subject, it behoves us to return to certain separations that we make starting with the most common between transcendence and immanence, or between God above and humanity below. For Maurice Bellet, "the gap between Heaven and Earth is within us"72 and not outside. The real separations are now made elsewhere, between horror and love, between tenderness and cruelty. That is why, he will write in one of his most beautiful pages that "There is no such thing as the soul apart from God; there is God in us" (Il n'y a pas l'âme et Dieu; il y a Dieu en nous) ${ }^{73}$; or, between me and you, "God does not add Himself, He manifests Himself in us" (Dieu ne s'ajoute pas, il s'y manifeste) $)^{74}$.

This is the "unheard of" who now lives in our humanity, and whom we can only reach by really becoming as human as possible. Only in this way may God rise ${ }^{75}$ because, $\mathrm{He}$ is free "to be where He wants and when $\mathrm{He}$ wants, completely outside our discourse [...] a rising God." 76 This last expression, taken from the book Le Dieu sauvage, will be completed in another

\footnotetext{
${ }^{66}$ Ibidem.

${ }^{67}$ Ibidem.

${ }^{68}$ Ibidem.

${ }^{69}$ Ibidem, 114.

${ }^{70}$ Ibidem, 115.

${ }^{71}$ Ibidem, 208.

${ }^{72}$ Idem, Un chemin sans chemin (Paris: Bayard, 2016), 100, apud Tonus, Ouvrir l'espace du christianisme, chap. 4, sub-chap. "Ouvrir l'espace".

${ }^{73}$ Idem, La longue veille, 187.

${ }^{74}$ Ibidem, 234.

${ }^{75}$ Difficult term to translate: surgir, in the original French, echoing Bellet's expression un Dieu surgissant.

${ }^{76}$ Bellet, Le Dieu sauvage: Pour une foi critique (Paris: Bayard, 2007), 179.
} 
book, Dieu personne ne l'a jamais vu, with that of "God rising in humanity" (Dieu surgissant en humanité) ${ }^{77}$.

Finally, there is one last place where God rises par excellence: it is man's agape. The usual translation ("love", "charity") is no longer good enough for Maurice Bellet. It must rather convey the sense of "the new humanity which begins in Jesus Christ and which is about growing into fullness ${ }^{78}$. Now, in order for this sentence to pass from discourse into reality, one needs to have this lively awareness that Christ, having taken on our human nature, allows us to say from now on: "we are this man" (nous sommes cet homme) ${ }^{79}$. This is the grand finale of a discourse that should not be judged too quickly, but rather welcomed for what it is, that is to say, as the experience of a man who has "gone through fire."

\section{Conclusion}

Whether we think of ourselves as believers or non-believers, Maurice Bellet's thinking will never leave us indifferent. In a quite unexpected style, his writing blends faith and psychoanalysis, philosophy and poetry, doubts and certainties, violence and delicacy. If his personality is difficult to interpret, his thinking nevertheless continues to reach out. Since 1989, an Association named "Initial" 81 has been offering a training programme and study groups on Maurice Bellet's thinking, in towns all over France. Offering an opportunity for listening and sharing, the Association welcomes men and women who, in the wake of Maurice Bellet, continue to ask themselves what is at the heart of our humanity and what defines the essence of our faith. Reflection weekends are organized by the Association once a year but there are also courses of ten monthly sessions when members experience the freedom to share without being judged, and when the sensitivity of each one is respected.

His books, whilst enjoying a healthy readership in France, where Maurice Bellet is most widely known, are also translated into other languages: Italian, English, German, Spanish, Portuguese, etc. There must surely be also (as Bellet himself loved to say) an "invisible community" of readers. His thinking is not yet the subject of theological studies, apart from the one doctorate known at present, that of an Iranian Muslim, Seyed Djamal

\footnotetext{
${ }_{77}$ Idem, Dieu, personne ne l'a jamais vu, 93.

${ }^{78}$ Idem, "Les deux christianismes," 238-39.

${ }^{79}$ Ibidem, 244. The same as in his article "Christ à venir," Etudes, no. 12 (2000), 642: "His death, it's us; His resurrection, it's us".

${ }^{80}$ See his expression: "passer par le feu" (Bellet, "Passer par le feu," 271).

${ }^{81}$ http://www.initial.asso.fr/
} 
Moussavi Chirazi, on "L'évolution de l'écriture de Maurice Bellet". The thesis was defended in 1999 and Maurice Bellet refers to it briefly in La longue $v_{\text {ville }}{ }^{82}$. There are also two internet sites dedicated to him, one in French (https://belletmaurice.blogspot.com/) and the other in Italian (http://www. mauricebellet.it). Myriam Tonus, his most faithful collaborator and today the literary heir to his work, keeps a watchful eye on the spread of Maurice Bellet's thinking. Her book, Ouvrir l'espace du christianisme, is still the best introduction to the copious and puzzling thoughts of our author.

It is certain that as an unclassifiable writer, Maurice Bellet is more like a meteorite than a standard theologian. He comes from nowhere and yet.... one cannot help but feel a certain familiarity as we approach his writings. Very quickly they find an echo in us, they resonate with us, disturb us, scandalize us, put us back on our path again. But beyond such feelings, Maurice Bellet's work remains topical because of the questions it constantly stirs up: what can we do to ensure that the message of the Gospel remains audible in a world that is indifferent? How can we overcome the division, which causes so much damage, between Christianity and this very world we are speaking of? How can we reach out to the lived experience of men and women? - of every human being? How can we recognize in our humanity the universal action of Jesus Christ? It goes without saying that, faced with the present urgency, it is no longer a question of pushing these questions into a distant future. We must respond to them now. A brilliant figure, Maurice Bellet died on April 5, 2018, at the age of 94. His last moments, like a summary of all his work, are conveyed to us in Myriam Tonus's book:

When the priest who came to administer the last sacraments asked him if he wanted to say something to the residents of the retirement home where he lived, Maurice Bellet replied simply: "Tell them that I love them..." Then he repeated one of his favourite sentences, in Greek: $O \theta \varepsilon \dot{s} \varsigma \dot{\alpha} \gamma \alpha \dot{\alpha} \pi \eta$

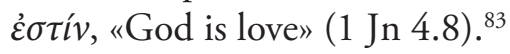

\footnotetext{
${ }^{82}$ Bellet, La longue veille, 282-83.

${ }^{83}$ Tonus, Ouvrir l'espace du christianisme, chap. 1, sub-chap. "Dis-leur que je les aime".
} 